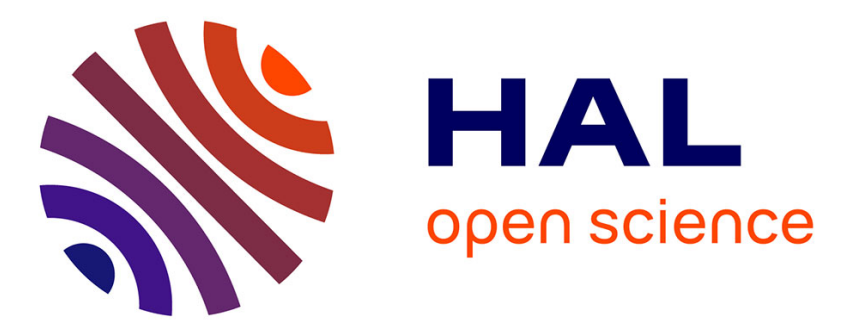

\title{
Automated Speed Enforcement: What The French Experience Can Teach Us
}

Laurent Carnis

\section{To cite this version:}

Laurent Carnis. Automated Speed Enforcement: What The French Experience Can Teach Us. Road Safety 2020: Smart Solutions, Sustainability, Vision The Australasian College of Road Safety Conference, Nov 2009, Perth, Western Australia, Australia. hal-00430965

\section{HAL Id: hal-00430965 https://hal.science/hal-00430965}

Submitted on 13 Nov 2009

HAL is a multi-disciplinary open access archive for the deposit and dissemination of scientific research documents, whether they are published or not. The documents may come from teaching and research institutions in France or abroad, or from public or private research centers.
L'archive ouverte pluridisciplinaire HAL, est destinée au dépôt et à la diffusion de documents scientifiques de niveau recherche, publiés ou non, émanant des établissements d'enseignement et de recherche français ou étrangers, des laboratoires publics ou privés. 
Automated Speed Enforcement: What The French Experience Can Teach Us

\author{
Carnis, L. \\ Département d'Economie et de Sociologie des Transports (DEST) \\ Institut National de Recherche sur les Transports et leur Sécurité (INRETS), France
}

\begin{abstract}
The French authorities installed the country's first speed cameras in November 2003 and at present some 2500 devices are in operation throughout the road and highway network. France has seen a significant decrease in the number of fatalities and injuries since the implementation of this speed enforcement programme. However, in comparison with its Australian counterparts, the French system functions differently and has its own special characteristics. An empirical analysis of this programme can yield new findings regarding the enforcement mechanism and could open up new avenues for traffic safety policy.

The first section of this article proposes a presentation of the French programme and how it is currently operated. The second section offers a detailed investigation into the deterrent effect and punishment policy, with emphasis on the specificities of the strategy followed by the French public authorities. The final section focuses on the political consequences of implementation of such a programme. This contribution highlights the insights the French ASE programme can yield for countries interested in installing such apparatus or in improving their own programmes.
\end{abstract}

\title{
$\underline{\text { Keywords }}$
}

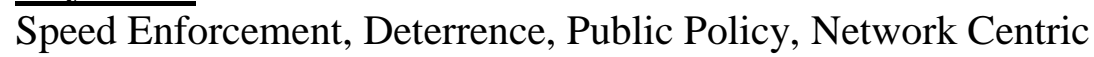




\section{Introduction}

Automation of speed checks represents a major change in road safety policy in France in recent years. It is part of a broader policy of punishing illegal driving behaviour and reinforcing the penalties incurred by offenders. This campaign against road violence ${ }^{1}$ foregrounds a political determination to put an end to impunity for those whose behaviour endangers, among other things, the lives of others.

This public policy has yielded remarkable road toll statistics. The number of fatalities has diminished by over $40 \%$ since 2002, and the authorities are speaking of 12,000 lives saved since the new policy was implemented. The number of injuries avoided is also considerable, even if the fatality figures are those that draw most attention from official decision-makers and the media.

Introduction of the automated speed enforcement (ASE) system took place in a favourable context, the then President Jacques Chirac having expressed a personal commitment and made road safety a priority for his term in office. The French system of automatic speed enforcement has its own distinctive form of organization and revolves around a number of basic principles (section 1 of this article). Study of the French ASE stresses the use of an innovative strategy for deterring speed limit offences. The authorities opted for a mixed strategy utilizing "network-centric" deterrence. In addition, installation of an automatic system necessitates consideration of its effects on the division of labour within the deterrence framework (section 2). The acquisition of such a system hinges on a deliberate political choice, which in turn requires a favourable political context and ongoing backup as a means of resisting the system's opponents. All in all, automatic speed enforcement signals the coming of a new age in public road safety policy (section 3 ).

\section{Presentation of automatic speed enforcement in France}

The introduction of an automatic speed enforcement system in France represents a major change in public sector road safety policy over the last few years. This section presents the circumstances of its ongoing installation, its organisational structure and its basic operating principles.

\section{A favourable context and a gradual rise in impact}

In his presidential speech of July 2002 Jacques Chirac made the first mention of the introduction of an automatic speed enforcement system in France. In December of the same year the Interdepartmental Road Safety Committee (CISR) officially announced the establishment of the system in the course of 2003, with the first checking devices to be installed in the course of that year (Carnis 2007).

Introduction of the system was facilitated by a favourable political agenda, President Chirac having decided to make road safety a priority concern for his term of office. The intention was to implement a resolute road safety policy aimed at effective application of the Highway Code provisions and breaking with past practice characterised by random, ineffective speed limit enforcement (Carnis 2008a).

In November 2003 the first radar speed traps were installed, with the authorities planning the introduction of 500 new units per year. By the end of 2007 it was announced that over 1850 devices were fully operational. ${ }^{2}$ By September 2008 the number had risen to over

\footnotetext{
${ }^{1}$ Law of 12 June 2003.

${ }^{2}$ Information provided by DPICA (Interdepartmental Automatic Speed Enforcement Project) in April 2008.
} 
2200. At the meeting of the CISR in February $2008^{3}$ the government announced a further 2000 devices by 2012, an annual increase of 500. At present 2500 devices are in place on the road network, the aim being a total of 2800 for the end of 2009. (Mariton 2009) In the first half of 2009 the first red light cameras were installed, with a total of 150 planned for the end of the year.

\section{Organization}

The French system uses a form of digital technology allowing for near-complete automation of the detection and penalty procedure. The offender may pay his fine without having had any contact with a police officer, judge or state representative.

The French ASE programme uses fixed devices which, according to their generation, take photographs of offending vehicles front on or from behind. Mobile on-board devices (some of which could operate outside the vehicle) are also part of the programme.

The infractions detected by different checking units (fixed or mobile) are communicated to the National Processing Centre (CNT) in Rennes, where they are computerprocessed. The centre then draws up the documents needed for legal action regarding the infractions recorded. Given that the procedures are all automated, the centre has a high processing capacity and can cope with a very large number of infractions. In addition it is reliable (there are very few challenges) and fast (most fines are communicated to the offender within a week of the offence). In 2008 alone the system sent out 17 million traffic infringement notices, with the total since 2003 running at over 57 million.

The Interdepartmental Automatic Speed Enforcement Project (DPICA) handles the strategic side - monitoring of the installation and functioning of the devices - and decisionmaking: number and location of devices, issuing of contracts, etc. It also has a communication role and looks after relationships with Prefects (the principal state representatives in each département) and such political decision makers as mayors and members of Parliament. ${ }^{4}$ Headed up by a Prefect, it also includes advisors from the National Police and the Gendarmerie, and expert analysts.

\section{Main functioning principles}

To my knowledge there exists no official document specifying installation criteria for speed detection devices (Carnis 2008b, pp. 225-226; Canel and Nouvier 2004). The choice of localities should in theory reflect perceived dangers, excess speed problems or the impossibility of using traditional detection methods, but in fact this choice also points up the existence of technical constraints and political trade-offs (between centre and periphery).

Fixed detection devices function on a fulltime basis - except in cases of breakdown or wilful damage - while the mobile ones, whose setting-up requires the presence of police personnel - are used less and discontinuously. The authorities have opted for signalling the presence of devices, warning road users with a standardised sign placed ahead of the detection point. Detection points are also publicised on the official road safety site on the Internet. $^{5}$ Mobile devices, however, are not signalled. Detection in these cases is effected using unmarked, specially equipped cars used solely for this purpose.

In France a speeding offence leads to a fine and the deduction of driving licence points (of which the initial total is 12). The penalties for speeding offences do not depend on the

\footnotetext{
${ }^{3}$ Interdepartmental Road Safety Committee (CISR) press kit, 13 February 2008, 22 pp.

${ }^{4}$ DPICA members were heard as part of the background report for the Commission of Finance, the Economy and Planning on the revenues generated by speed fines and the financing of the road safety policy.

${ }^{5}$ www.securiteroutiere.gouv.fr
} 
method of detection used: whether detected by a "traditional" method or an automatic device, a given offence carries the same penalty. Automatic devices detect offending vehicles, with the owner presumed to be the driver. Thus the owner is automatically considered responsible for the offence. He may appeal this responsibility by designating the person who was driving the vehicle at the time of the offence, but he must first pay the fine, which is held as a deposit and repaid in the light of the final decision. In cases where the driver cannot be identified, the owner of the vehicle is obliged to pay the fine, even if the procedure does not entail a loss of licence points.

The authorities have also opted for systematic elimination of all photos likely to generate challenge. In practice more than one photo in two is rejected, in the interests of quality and of maintaining public confidence in the functioning of the system. Automation of the procedure also excludes the once current practices of tolerance and indulgence: equity is one of the goals of the system and requires that each citizen receive identical treatment, whence the importance of keeping the system impervious to external influences. A further characteristic of the system is its rapidity: $80 \%$ of all fines are paid within 45 days (source: ONISR - National Interdepartmental Road Safety Observatory, 2006). Thus efficiency, rapidity, reliability and equity are the underlying principles applied by the authorities in implementing a policy the public will consider as both credible and acceptable.

\section{Conclusions to be drawn regarding speeding deterrence policy}

Automatic speed enforcement has generated an enormous literature (Elvis and Vaa 2004) from which recommendations for public policy can be drawn. The French experience highlights the benefits accruing from use of a mixed strategy and network-centric deterrence. Automation of controls also necessitates thinking about the implications for the establishing of a new division of labour in the field of deterrence.

\section{Mixed strategy, hybrid system}

Implementation of a policy for deterring excessive speed via an automatic enforcement system requires advance definition of a number of parameters. Thus the authorities must decide if the aim of their policy is general deterrence (deterring the committing of offences) or/and specific deterrence (detecting the offence and punishing the offender) (Cameron and Sanderson 1982). In concrete terms this means deciding whether or not to indicate the presence of checks, finding the appropriate signing, and opting for fixed or mobile devices.

The French authorities decided in favour of a mixed strategy combining signalled and hidden devices (mobile devices are operated from inside unmarked police cars), with a view to achieving both general and specific deterrence. The fixed devices are preceded by signals intended to modify driver behaviour in terms of excess speed, with their quantity and continuous functioning enabling the creation of "recurrence" or "resonance" effects (zones under full-time surveillance). All in all the point is to educate drivers towards new behaviours via repeated reminders of the law. The mobile devices are used to detect and punish offenders, which explains why their presence is not signalled. Their mobility allows for numerous random checkpoints on the road network and this generates a situation of widespread uncertainty (Carnis 2008c).

The combination of these two elements provides a system which is both effective and acceptable to drivers. Its effectiveness resides in the dual education/deterrence approach, while acceptability can draw strength from a system not intended as exclusively punitive. 
The Australasian College of Road Safety

Road Safety 2020: Smart Solutions, Sustainability, Vision, Conference Proceedings, 5-6 November 2009

Duxton Hotel, Perth, Western Australia

Overall this mixed strategy reflects a hybridisation of the system with a view to meeting the need for both effectiveness and acceptability.

\section{Creating "network-centric" deterrence}

Official policy can aim at local deterrence, with a view to modifying behaviour in respect of a dangerous infrastructure (a tunnel, for example); route deterrence (over a road or highway as a whole); or global deterrence (not limited to the section under surveillance, but rather extending to other, non-checked sections of the network).

The French authorities opted for a progressive gridding of the road network, so as to ensure that whatever route a driver takes, he must at some point encounter a speed trap. The increasing number of such points on the country's roads and freeways can be interpreted as a deployment of sensors covering the entire territory and sending a message to drivers about the sheer difficulty of avoiding speed checks. What we have, then, is a nationwide detection network overlaid on the road network yet not merging with it. Moreover, the number and diversity of detection points makes their identification difficult and costly for the driver (even if currently available warning facilities reduce these costs).

This network-centric aspect of deterrence relies on nodes interlinked by their access to the National Processing Centre. The sheer massiveness of the system comprising 4500 detection points in 2012 (and no doubt more in the years to follow), the interdependence of those points and their incorporation into a single unified programme constitute the basis of a network-centric deterrence (Joffe 2007-08, p. 927) distinct from the practices classically observed in other countries.

\section{Deterrence and a new division of labour}

Organizing the work of deterrence within police bodies is a complex task. A police force is a productive organization which must provide different services by combining numerous productivity factors (Carnis 2009a). The choices involved are far from easy for the decision maker, who does not always have the necessary information at his disposal.

Moreover, putting this process to work is a tricky business in many respects. There is competition from other productive activities within the same organization - public safety, for instance - while for the organization's members this activity most often seems lacking in prestige and is thus perceived as unattractive.

Thus a police force is built around a multiservice organization whose numerous responsibilities include public safety and road safety. In the case of the latter, to narrow the work of police bodies to the merely punitive would be reductive and mistaken, given that the police provide a host of services (emergency assistance, post-accident safety measures, escort assignments); that they work with schools; and that they take part in educational and training activities (Carnis et al. 2006). Thus the issue of the allocation of resources to combat various kinds of offences - speeding, failure to wear a seat belt, alcohol and drug use - adds fresh difficulties for the decision maker.

Automatic speed enforcement represents a technical innovation in the production of road safety services, and as far as I can ascertain its impact on police organization and the work of the traffic policeman has never been studied. There exists a host of different possibilities for the implementing of ASE (Carnis 2009b). Automation can lead to the subcontracting of some tasks to the private sector (data processing, speed checks carried out by operatives); and entrusting of certain police functions to administrative personnel. Police work can also be replaced by totally automatic systems. In this way automation can free up police resources for other tasks. In concrete terms, automation of speed checks calls for a 
redefinition of the functions of traffic police, and a new division of labour between the organizations involved that requires study in its own right.

Automation also means that the authorities now have at their disposal a range of activities (traditional checks and automatic detection with its various modalities) and resources (equipment and personnel) which they must combine optimally in the interests of deterrence (Cameron 2008). The allocation of these facilities may reflect an economic analysis of the situation: it must also take account of empirical lessons regarding deterrence policy (Cameron et al. 2003), and at the same time come to terms with the existence of private sector alternatives for behaviour regulation (Young and Regan 2007). In addition, this public sector decision is part of a specific institutional framework (police jurisdictions, initial equipping of police forces, legal constraints, etc.) and must correspond to citizen values in respect of the protection of privacy, public safety, etc.

To keep things simple and to limit my analysis to the deterring of speeding, I should point out that the introduction of ASE can have two distinct effects on the global effort put into speed detection.

The first of these can be termed complementarity. ASE represents a public sector gambit which complements the traditional checks carried out by police bodies. In France the installation of automatic radar speed traps has not caused any reduction in the number of offences recorded by the police. On the contrary, the total has risen slightly. This is worth noting in that the use of mobile devices requires the presence of police personnel. Automation of the detection process is seen as a means of increasing the effort put into deterring potential speeding offenders.

The second effect has to do with a process of substitution or commutation. In concrete terms this means total replacement of traditional checks by automatic detection. In this situation automation is aimed more at improving productivity - boosting the number of offences detected per hour of surveillance, for example - than of increasing the total number of detection hours. ${ }^{6}$ The British context provides a good illustration here, as automatic detection of speeding violations has led to a substantial reduction in the number of police officers working in the road safety field. (PACTS 2005, p. 11) Thus the automation of speed detection reflects public policy choices that are not always made explicit. These aspects of the issue also need to be taken into account when the effects of the introduction of such a system have to be assessed.

\section{The political issues related to automatic speed enforcement}

Establishment of an automatic speed enforcement system reflects a number of political trade-offs. It represents a specific public sector intervention whose analysis can bring to light various aspects crucial to its implementation. Automation of detection points to a new age for public road safety policy, which can only advance in a favourable political context.

\section{A new age for public road safety policy}

Speed regulation is the outcome of a long historical process: of the accumulation of major political decisions, the ongoing advance of scientific knowledge, extensive debate and numerous back-and-forth shifts in terms of rules $^{7}$ (Cohen et al. 1998; TRB 1998). Automation

\footnotetext{
${ }^{6}$ Installation of an automatic device functioning fulltime also enables an increase in the total number of hours of surveillance.

${ }^{7}$ The United States are an iconic example, given the changes in speed limits that have taken place there since the mid-1970s.
} 
The Australasian College of Road Safety

Road Safety 2020: Smart Solutions, Sustainability, Vision, Conference Proceedings, 5-6 November 2009

Duxton Hotel, Perth, Western Australia

of speed detection can be interpreted as pointing to the coming of a new age in public road safety policy.

Initially the authorities' task was identification of the main contributing factors in the road toll. In France the first ventures into speed regulation date from the early 1960s, for traffic in built-up areas. It was only in the early 1970s, however, that speed limits were set for national highways and the freeway network; this followed local experiments, the first of which dated from...1959! At the same time studies were carried out on the impact of speed limits in many different foreign countries. This slow maturation of the relevant knowledge aided public sector decision makers when steps had to be taken to regulate behaviour on the roads.

There then followed the second phase of public intervention: the establishing of best practices for making road safety regulation effective. The country's police forces had to be mobilised, equipped and trained in enforcement. The implementation of centralised decisions by devolved organizations all over the country was a more or less difficult process finally crowned with success. The devolved authorities had to adapt these centralised decisions to their own terrain and come to terms with local and peripheral actors, the outcome including various forms of tolerance and indulgence as well as haphazard speed checking of traffic networks. (Pérez-Diaz 1998) The issues were strategic, too: there had to be trade-offs in general surveillance of the network, but with arrests of offenders guilty of dangerous driving practices (which remained extremely ill-defined).

The move to automatic speed enforcement constitutes a recognition of the dangers of excessive speed on the roads and to a certain extent expresses a consensus among the population regarding the penalizing of this kind of behaviour. (There thus exists minimal support from the public and from state agents for the introduction of such a system.) Automation of detection not only allows for the removal of most of the operational constraints involved (this is especially true of the fixed devices), but also facilitates the choice of location and timing and - via the number of offenders identified - evaluation of the system's effectiveness. For the authorities the problematics of the current situation lies in timing, location and surveillance density level, the aim being to produce optimal deterrence, use the system to the best advantage and allocate resources as efficiently as possible. The system's redoubtable operational efficiency nonetheless raises questions of equity: technical trustworthiness becomes a major aspect in that margins of tolerance are reduced, while equitable treatment of offenders, the legality of the procedure and proportional appropriateness of the penalties represent new matters for the authorities to deal with. There are issues of transparency, too, which find expression in debate about the use of the accrued revenue for specific purposes, so as to avoid accusations that the government is seeking new forms of tax income; about the criteria for the location of the devices; about the standard margin of error; and about the laying down of appropriate penalties and a clearly established procedure. There is also the question of a regular public evaluation of the ASE. Lastly, the authorities must do all in their power to make the action taken "acceptable" to road users, a situation which, among other things, requires the drawing-up of a communication policy on aims and results. Whereas the launching of the French system was the subject of no public awareness operation whatsoever, ${ }^{8}$ the authorities have recently begun a backup campaign titled "The 12,000 Lives", which foregrounds road safety gains since 2002. The campaign's positive message is that those who have gained most from the new policy are those

\footnotetext{
${ }^{8}$ Nonetheless, the launch of ASE had the backing of the media - TV, local and national press - which presented the government initiative in a favourable light. Overall the system has benefited from approval by the media generally. An interesting account is to be found in the postgraduate thesis by Yann Even, La sécurité routière dans la presse quotidienne de juillet 2000 à juin 2003, "Un effet Chirac", Université Saint Quentin en Yvelines, 2003.
} 
anonymous folk who continue to lead normal lives when they might have been victims of a fatal or severely handicapping accident.

All in all, the new age augured by automatic detection of traffic offences makes it clear that for the authorities it is less a question of identifying the factors contributing to the road toll - these now being known to and accepted by the population as a whole - or of ensuring effective application of the road rules by mobilizing and organizing the means appropriate to carrying out detection, but rather a question of making the right strategic choices regarding the deployment and use of the devices, while informing the population about what is being done and how.

\section{The political aspect}

Setting up an ASE system involves implementing a specific public policy and thus a very real political choice (Carnis et al 2008). The most conclusive illustration of this is the explicit commitment of the then President Jacques Chirac to the road safety campaign in making the issue a priority for his term of office. This political commitment was equally displayed by successive ministers of Transport and the Interior, who made the struggle their own and systematically defended the programme against attacks by its critics. ${ }^{9}$ This increased engagement with road safety issues by political decision makers had already emerged from the debate on the timeliness of pursuing the policy of amnestying road traffic offenders. ${ }^{10} \mathrm{An}$ advisory committee had been set up to assess the effects of this practice on the road toll (Bergel et al. 2002) with a view to limiting its scope. This commitment at the highest state level also allowed for the effecting of change in police practices, notably in terms of motivating personnel who now saw themselves doing a respected job and generously provided with new, high-performance equipment. Despite their "corporate" differences, both the police and the gendarmerie willingly integrated the new systems into their way of working, and their commitment has played its part in the excellent results obtained in respect of the road toll (Carnis 2008b).

The political aspect needs to be seen in a broad sense, and not merely in terms of the role of centralised state decision makers. The project has also been extremely well received by local political actors: the prefects have played their part as intermediaries for the départements, while mayors and département councillors have requested the installation of the system on their territories. The courts have also aligned themselves with the new policy by systematically upholding the system's decisions when these come under challenge. Furthermore the system has received the media support and moral endorsement of experts and those in charge of road accident victim associations, who have fought tooth and nail for the system. Lastly, the population as a whole has "altruistically" accepted implementation of the system (ONISR 2006, p. 47 sqq.).

However, the highly favourable political context of the early years seems to have changed somewhat. A number of specialist automobile magazines publish regular attacks on the system, notably in respect of its (in)correct use by the police and the accuracy of the devices. The aim here is to undermine the system's legitimacy. Certain lawyers have specialised in the defence of drivers deprived of their licences, ${ }^{11}$ trumpeting their successes in exposing legal shortcomings within the system and being extremely well paid at the same time. More recently the Council of State handed down a decision ordering the Ministry of the Interior to establish a real relationship between the penalty imposed and the danger

\footnotetext{
${ }^{9}$ Angélique Négroni, "Excès de vitesse: MAM défend une répression ferme", www.lefigaro.fr, 10 April 2009.

${ }^{10}$ A traditional follow-up to a presidential election in France.

${ }^{11}$ Angélique Négroni, "Radars: ces avocats qui courtisent les automobilistes", Le Figaro, Monday 25 May 2009, no. 20160 , p. 2 .
} 
The Australasian College of Road Safety

Road Safety 2020: Smart Solutions, Sustainability, Vision, Conference Proceedings, 5-6 November 2009

Duxton Hotel, Perth, Western Australia

represented by the driver. ${ }^{12}$ In addition, certain parliamentarians have taken action to have the penalties modified, so that a speed of less than $5 \mathrm{kph}$ over the limit should not cost a licence point $;^{13}$ and in some cases the courts have discharged defendants on the grounds of a doubt as to the accuracy of speed measurement, even when the speed in question was recognised as excessive. $^{14}$

Effective introduction of an ASE system and its maintenance require a favourable political context. Those in favour must make their point of view clear and provided organised defence of the system, given that its opponents are not slow to speak up. Public consent to the use of the system must be maintained via sound communication and transparency of functioning. The trustworthiness, equity and efficiency of the system require particular attention on the part of the authorities; and when necessary, corrective measures must be taken to improve functioning and ensure continuing user support.

\section{Conclusion}

The French system of Automatic Speed Enforcement is an innovative experiment in speed regulation. It differs from its European and Australian counterparts in its modalities, its functional principles and its institutional character.

Detailed analysis enables stress on the major contributions to deterrence policy regarding speed limit offenders. The system's strategic aspects cannot be reduced to an exclusive choice between distinct strategic modalities; rather they call for a trade-off between different, simultaneously applied detection strategies and modalities. The authorities work with a set of options which they adapt as best they can to their specific territories. In France they have also opted for a network-centric form of deterrence explicable in terms of, among other things, a totally automatic approach. Study of the French system highlights the fact that introduction of this system took place in a specific institutional framework which may, as a result, be modified and give rise to a new division of labour as regards deterrence.

Lastly, the introduction of the system expressed a public-sector policy whose success resides in, among other things, a favourable, lasting political configuration. Doubtless the quest for public support for this policy is opening up new possibilities for public sector intervention in road safety. The political significance of automation of detection methods calls for detailed studies of the various systems used with a view to identifying points of convergence and achieving an understanding of specifically national differences

\footnotetext{
${ }^{12}$ Conseil d'Etat, 13 March 2009, no. 322303.

13 Angélique Négroni, "Polémique autour des petits excès de vitesse", Le Figaro, Wednesday 18 March 2009, no. 20103 , p. 9.

${ }^{14}$ Angélique Négroni, "Des juges préfèrent relaxer des conducteurs flashés", www.lefigaro.fr, Le Figaro, 28 July 2009.
} 


\section{References}

Bergel, R., Carnis L., Le Breton, P., Le Tertre, A., Page, Y., Thelot, B., Uhry, Z. 2002. Amnistie présidentielle et sécurité routière: rapport d'un groupe d'experts, INRETS, Rapport d'expertise

Cameron, M. 2008. Development of Strategies For Best Practice in Speed Enforcement in Western Australia: Supplementary Report, Monash University Accident Research Centre, May, Report $\mathrm{n}^{\circ} 277,50 \mathrm{p}$.

Cameron, M., Delaney, A., Diamantopoulou K., Lough B. 2003. Scientific Basis For The Strategic Directions Of The Safety Camera Program in Victoria, Monash University Accident Research Centre, report $\mathrm{n}^{\circ} 202$, viii +70 pages,

Cameron, M., Sanderson J.T. 1982. Review Of Police Operations For Traffic Law Enforcement, Royal Automobile Club Of Victoria (RACV) Ltd. Report n ${ }^{\mathrm{o}}$ TS 82/5.

Canel, A. et Nouvier, J. 2004. Sécurité routière et contrôles automatiques en France : résultats et perspectives, Routes - Roads, n²35, Octobre, pp. 54-60.

Carnis, L. 2009a. Une analyse économique du dispositif de contrôle automatisé de la vitesse en France, Proceedings of the 19th Canadian Multidisciplinary Road Safety Conference, Saskatoon, Saskatchewan, 8-10 June 2009, Peer-Reviewed Paper, pp. 1-17.

Carnis, L. 2009b. L'automatisation des contrôles de vitesse, les nouvelles technologies et le gendarme, Futuribles, Analyse et Prospective, n³53, juin 2009, pp. 25-37.

Carnis, L. 2008(a). Automated speed detection and sanction system: application and evaluation in France", Journal of Intelligent Transportation Systems, (12)2: 75-85.

Carnis, L. 2008(b). Le contrôle automatisé de la vitesse en France et en Grande-Bretagne. Deux régimes de régulation des vitesses distincts, in Delorme, $R$. et Lassarre, $S$. Les régimes français et britannique de régulation du risque routier, Les Collections de l'INRETS, synthèse n'57, pp. 201-232.

Carnis, L. 2008(c). The French automated speed enforcement programme: a deterrent system at work, Proceedings of the 2008 Australasian Road Safety Research, Policing and Education Conference, Peer-Reviewed Paper, Adelaide, South Australia, Australia, pp. 752-766, $9^{\text {th }}-12^{\text {th }}$ November 2008.

Carnis, L. 2007. The French automated speed enforcement programme: first results and analysis", Proceedings of 2007 Australasian Road Safety Conference Research Policing Education Conference, Peer-Reviewed Paper, Melbourne, Victoria, Australia, 17-19 October 2007, http://www.roadsafetyconference2007.com.au/finalpapers.php.

Carnis, L., Rakotonirainy, A., Fleiter J. 2008. Speed Enforcement Programmes in France and Queensland: First Elements for a Systematic Comparison, Proceedings of the 2008 Joint Australasian College Road Safety - Travelsafe National Conference, 18-19 September 2008, Peer-Reviewed Paper, Brisbane, Queensland, Australia, pp. 40-53.

Carnis, L., Hamelin F., Spenlehauer V., 2006. Les polices de la route, Une approche comparée Etats-Unis, Nouvelle-Galles du Sud et Nouvelle-Zélande, Les collections de l'INRETS, Rapport n 269.

Cohen, S., Duval, H., Lassarre, S., Orfeuil J.P. 1998. Limitations de vitesse, les décisions publiques et leurs effets, HERMES.

Elvik, E., Vaa T. 2004. The Handbook of Road Safety Measures, Police Enforcement and Sanctions, chapter 8, Elsevier.

Joffe, J. 2007-2008. L'état de la guerre au XXIe siècle, Commentaire, n¹20, Hiver, pp. 927 933.

Mariton, H. 2009. Rapport d'information déposé en application de l'article 146 du règlement par la Commission des finances, de l'économie générale et du plan sur les amendes radars et le financement de la politique de sécurité routière, Assemblée Nationale, 6 mai 2009. 
The Australasian College of Road Safety

Road Safety 2020: Smart Solutions, Sustainability, Vision, Conference Proceedings, 5-6 November 2009

Duxton Hotel, Perth, Western Australia

ONISR (Observatoire National Interministériel de Sécurité Routière). 2006. Impact du contrôle sanction automatisé sur la sécurité routière (2003-2005), évaluation, Les Rapports, Paris.

PACTS (Parliamentary Advisory Council for Transport Safety). 2005. Policing Road Risk: Enforcement, Technologies and Road Safety, Occasional Research Reports, September.

Pérez-Diaz, C. 1998. Jeux avec des règles pénales, L'Harmattan, Collection Logiques Sociales, Déviance/CESDIP.

Transportation Research Board. 1998. Managing Speed, Review Of Current Practice For Setting and Enforcing Speed Limits, Special Report 254, National Research Press.

Young, K. L., Regan, M. A. 2007. Intelligent Transport Systems To Support Police Enforcement Of Roads Safety Laws, ASTB Research and Analysis Report, Road Safety Research Grant 2007-02, Australian Transport Safety Bureau (ATSB), Australian Government, April, 62 p. 